\title{
UTILIZATION OF "RED MUD" BEING A PART OF NEW EFFECTIVE ADSORBENT IN WATER TREATMENT
}

\author{
S.O. Kyrii, I.V. Kosogina, I.M. Astrelin, V.Yu. Mosiyuk \\ National Technical University of Ukraine "Igor Sikorsky Kyiv Polytechnic Institute”, Kyiv \\ e-mail: kosogina@email.ua
}

Storage of red mud, because of its large quantity and specific compounds, causes a lot of problems. Thereby, development of complex technology utilization of wastes (red mud) is the most economically and environmentally attractive way to solve the problem of red mud accumulation and obtaining of highly efficient purification reagents from secondary raw materials.

The purpose of this work is synthesis and verification of efficacy of adsorption reagents that were obtained by using "red mud" in technologies of wastewater treatment from compounds of organic origin.

The proposed sorption reagent derived from activated "red mud" and activated carbon brand F300 revealed sufficient sorption efficiency at wastewater treatment from the dye "Active brilliant blue $K X^{\prime \prime}$. At the the initial concentration of dye 10, 30, $50 \mathrm{mg} / \mathrm{l}$ dye extraction to 84-100\% in following conditions was achieved: $\mathrm{pH}$ medium $4-4,3$, dose of sorbent $12 \mathrm{~g} / \mathrm{l}$, asdorption duration $150 \mathrm{~min}$.

Conducted research revealed that synthesized sorbent based on activated "red mud" and activated carbon (where activated carbon functionates as carrier) has potential for use in water treatment to remove organic dyes.

Key words: red mud, sorption reagent, sorption, utilization, waste, water purification.

\section{Introduction}

Every year the question of recycling industry waste that accumulate in large quantities becoming more acute. In this case, the similar object of environmental focus is the large-tonnage production of alumina from bauxite by the Bayer method with the waste formation that called "red mud".

According to various estimates, the annual accumulation of "red mud" on a world scale is from 60 to 120 million tons/year [1]. In Ukraine significant volume up to 1,5 million tons/year of wastes is produced by Mykolayiv Alumina Plant.

A significant disadvantage of red mud, that makes it difficult to use, is high humidity (about 80\%), and the existing sludge dewatering technologies are too energy-intensive and ineffective. In addition, the development of standards and technical regulations of sludge preparation, transportation and sludge usage should be aware that with the humidity $8-12 \%$, dry sludge undergoes wind deflation.

There are several ways of utilization process for "red mud" [2-5]. At first, it is regeneration of "red mud" useful components (eg, metals) [6-10]. At second it is a usage of "red mud" as a secondary raw material in the production of building materials (cement, bricks, foam blocks) [11-13]. At third it is the use of "red mud" in water purification technologies, such as reagents for water, including sorbents. The usage of "red mud" as sorption reagent can take a significant niche in its utilization because today adsorption is one of the most common processes 
for the removal of organic pollutants and heavy metals from the contaminated water. The remaining methods have limitations due to significant financial investment and maintenance and reagent costs.

The effectiveness of adsorption purification is quite high and depending on the sorbent nature, structure and size of a specific surface area of sorbent. In water treatment technologies are used various artificial and natural materials as adsorbents that have developed or specific surface (activated carbon, ash, peat, silica gel, alumogel, activated clay, polystyrene foam, etc). The economic feasibility of adsorption water treatment increases in case of using cheap materials as adsorbents. Typically, in water purification technology is using activated carbon, with the main advantages which include accessibility, availability of sufficient raw materials for its reception, non-toxic, etc. This to a certain extent compensates not very high adsorption degree of some pollutants. Therefore, it is actual the searching of modification method of activated carbon to improve its effective usage.

It is established that activated carbon can be modified by various ways that will help to improve the characteristics of the porous space. Particularly, using solutions of hydrochloric and nitric acids that followed by thermal shock [14], $\mathrm{HClO}_{4}$ with next-activation by carbon dioxide in an inert atmosphere $[15,16]$, alkaline reagents such as $\mathrm{NaOH}, \mathrm{KOH}, \mathrm{Na}_{2} \mathrm{CO}_{3}[17,18]$, salts and metal oxides, etc.

It is known that some compounds of transition metals (including iron) have a hydration capacity and it forms colloidal particles with a highly developed surface, and with inculcation to the activated carbon and can increase sorption capacity of activated carbon.

So, as the "red mud" contains a lot of iron compounds and also compounds of aluminum, titanium, it should be used as a raw material reagent for modification of activated carbon to obtain a composite metal-containing water purification reactant.

In water treatment technologies there is an urgent problem of removal organic dyes of various origins (they are widely used in various industries, including the textile, cosmetic, paper, plastic, pharmaceutical, food, etc.) from wastewater. At the same time, effective methods of wastewater treatment from organic dyes with using reagents from recycled materials, almost no.

\section{The purpose and objectives of research}

The purpose of this work are the synthesis and verification of efficacy of adsorption reagents, that was obtained by using "red mud", in wastewater treatment technologies from compounds of organic origin.

The following tasks were solved to achieve these goals:

1) Synthesize adsorption reagents by acid activation of "red mud";

2) Investigate the effect of following adsorption conditions on the efficiency of removal dye "Active brilliant blue KX":

- Effect of $\mathrm{pH}$ on the efficiency of water purification

- Effect of sorbent dose

- Effect of initial dye concentration "Active brilliant blue $\mathrm{KX}$ " on the effectiveness of its removal from water

- Effect of adsorption duration and initial dye concentration "Active brilliant blue KX" to the extent of its extraction.

\section{Materials and Methods}

\section{Investigated materials used in the experiment}

In the researches were used following materials:

1. The samples of "red mud" longstanding storage from landfills of Mykolayiv Alumina Plant. Depending on the quality of the raw bauxite and its processing features into alumina, the 
content of the main components of "red mud" varies (мас.\%): $40 \ldots 55 \mathrm{Fe}_{2} \mathrm{O}_{3}, 14 \ldots 18 \mathrm{Al}_{2} \mathrm{O}_{3}, 5 \ldots 10$ $\mathrm{CaO}, 5 \ldots 10 \mathrm{SiO}_{2}, 4 \ldots 6 \mathrm{TiO}_{2}, 2 \ldots 4 \mathrm{Na}_{2} \mathrm{O}[19,20]$.

2. Activated carbon brand Filtrasorb F300 (black pellets, grain size $0,80-1,00 \mu \mathrm{m}$, specific surface area $950 \mathrm{~m}^{2} / \mathrm{g}$ ). Before using of activated carbon F300 it was repeatedly washed with distilled water, and dried to constant weight at a temperature $105{ }^{\circ} \mathrm{C}(378 \mathrm{~K})$ and kept in a closed desiccator.

3. Inorganic acids $\mathrm{HCl}, \mathrm{H}_{2} \mathrm{SO}_{4}, \mathrm{HNO}_{3}$.

4. Dye "Active brilliant blue KX". It is dyhlortryazynovyy active dye, which belongs to the group of active organic dyes, typical for coloring cellulosic fibers and their products (Fig. 1). The content of the dye in the sample solutions $10 \ldots 70 \mathrm{mg} / 1$, that corresponding contaminant content in real wastewater.<smiles>Nc1c(S(=O)(=O)O)cc(Nc2ccc(S(=O)(=O)O)c(Nc3nc(Cl)nc(Cl)n3)c2)c2c1C(=O)c1ccccc1C2=O</smiles>

Figure 1 - The structural formula of dye "Active brilliant blue KX"

5. Sorption reagent (containing iron and aluminum and titanium additives), synthesized from alumina production wastes ("red mud") and activated carbon brand F300.

The degree of wastewater purification from organic dye by sorption reagent was evaluated by the photocolorimetric method at a wavelength $540 \mathrm{~nm}$.

Method of obtaining adsorption reagent

Synthesis of sorption reagents by acid activation of "red mud" is based on direct interaction with its inorganic acids, obtained after adding mixture of iron and aluminum salts to the activated carbon at temperatures $150{ }^{\circ} \mathrm{C}(423 \mathrm{~K})$ and with the partial consolidation of iron and aluminum compounds on the surface of activated carbon.

Activation was performed by the following procedure: a sample of "red mud" was dried to constant weight at a temperature $105^{\circ} \mathrm{C}(378 \mathrm{~K})$. Then it was loaded in the heat-resistant porcelain reactor with loaded calculated amount of acid and the "sample of red mud" and the dried activated carbon brand F300. Temperature condition of obtaining sorption reagents varied within $100 \ldots 350^{\circ} \mathrm{C}(373-623 \mathrm{~K})$ at varying duration of the activation process from 30 to $120 \mathrm{~min}$. The resulting product was cooled and crushed. Previous studies have found that the best related sorption capacity to clean polluted water occurs in coagulation reagents, synthesized with "red mud" at a temperature $150^{\circ} \mathrm{C}$ and with duration of the synthesis $60 \mathrm{~min}$. So hereinafter used sorption reagents, obtained under the same temperature and time conditions as for coagulants based on "red mud" [20].

\section{Methods of adsorption process}

The regularity of adsorption obtained sorption reagent studied in static conditions. The test of synthesized samples of sorbent insert in the polluted wastewater with the constant concentration of pollutants, then shaken with low intensity in the range from 20 to $180 \mathrm{~min}$. The sorbent was separated by decanting and spectrophotometrically determined the residual content of the dye in it. It was investigated the influence of adsorption reagent dose, duration adsorption, $\mathrm{pH}$ medium and 
dye concentration in the solution on cleaning efficiency of model samples of wastewater that containing $10 \ldots 70 \mathrm{mg} / \mathrm{l}$ dye "Active brilliant blue $\mathrm{KX}$ ".

\section{Research results and discussion}

\section{Effect of pH on the efficiency of water purification}

The value of $\mathrm{pH}$ is one of the most important parameters that affect on the efficiency of adsorption. Effect of different values of pH (from 2,75 to 8) on the efficiency of adsorption by synthesized sorbent with dye "Active brilliant blue $\mathrm{KX}$ " is shown in Figure 2. The initial concentration of the dye is $10 \mathrm{mg} / \mathrm{l}$, sorbent dose $5 \mathrm{~g} / \mathrm{l}$ and sorption duration $150 \mathrm{~min}$.

The sorbent was obtained by acid activation of "red mud" and its subsequent application on the activated carbon with the ratio $70 \%$ of red mud" and $30 \%$ of activated carbon F300 (synthesis temperature $150{ }^{\circ} \mathrm{C}$, synthesis duration $60 \mathrm{~min}$ ).

As can be seen from Figure 2, with $\mathrm{pH} 4-4,3$ regardless of the acid type, which was used in the synthesis of sorption reagent by activation of its components, the degree of discoloration of the dye reaches maximum $97 \%$ with presence $\mathrm{HCl}$ as activator of red mud. Therefore, further studies were carried out with $\mathrm{pH} 4-4,3$.

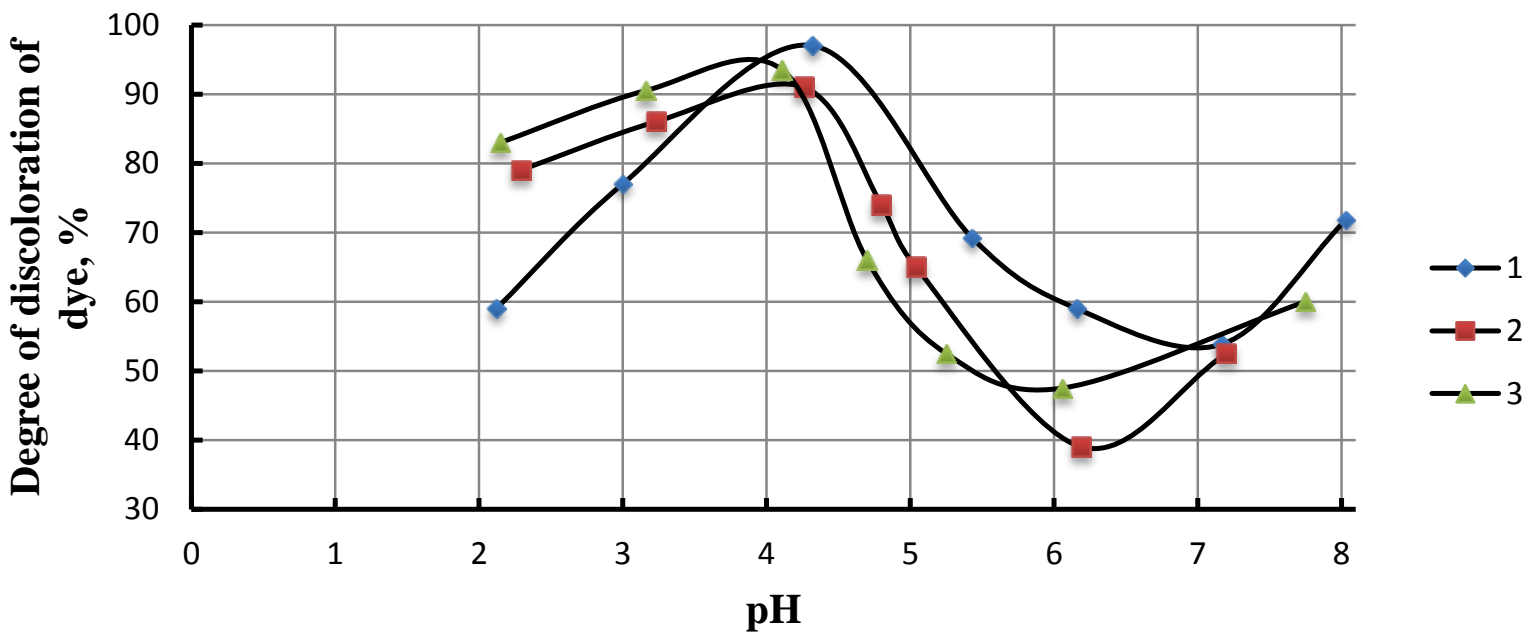

curve 1 - activator of red mud $\mathrm{HCl}$; curve 2 - activator of red mud $\mathrm{H}_{2} \mathrm{SO}_{4}$; curve 3 activator of red mud $\mathrm{HNO}_{3}$

Figure 2. Effect of $\mathrm{pH}$ medium on the efficiency of dye extraction by sorption reagents that were received with different activators

\section{Effect of sorbent dose}

Determination of the optimal dose of sorbent conducted in a range of $1-20 \mathrm{~g} / \mathrm{l}$ on the contaminated water with the content of dye "Active brilliant blue $\mathrm{KX}$ " $10 \mathrm{mg} / \mathrm{l}$ with the duration of sorption $150 \mathrm{~min}$ and $\mathrm{pH}$ medium within $4,1 \ldots 4,3$.

The effectiveness of the sorption purification by synthesized sorbent was compared with sorption data for activated carbon F300. Effect of adsorbent dose on the discoloration degree of dye by synthesized sorption reagent is shown in Figure 3.

It is established that changing of the dose of activated carbon F300 in the range $2-18 \mathrm{~g} / \mathrm{l}$ the degree of extraction of dye reaches a maximum only in $65,2 \%$. It necessitates modification conversion of activated carbon to improve the efficiency its performance.

But efficiency of dye adsorption on synthesized sorbent increases from 45,3\% to $100 \%$ with increasing doses of sorption reagent from 1 to $17 \mathrm{~g} / \mathrm{l}$. At a dose of sorbent $12 \mathrm{~g} / \mathrm{l}$ reached the 
degree of discoloration of wastewater by $99,9 \%$. So further research of adsorption conducted by this value of sorbent dose. The same dose selected for activated carbon F300.

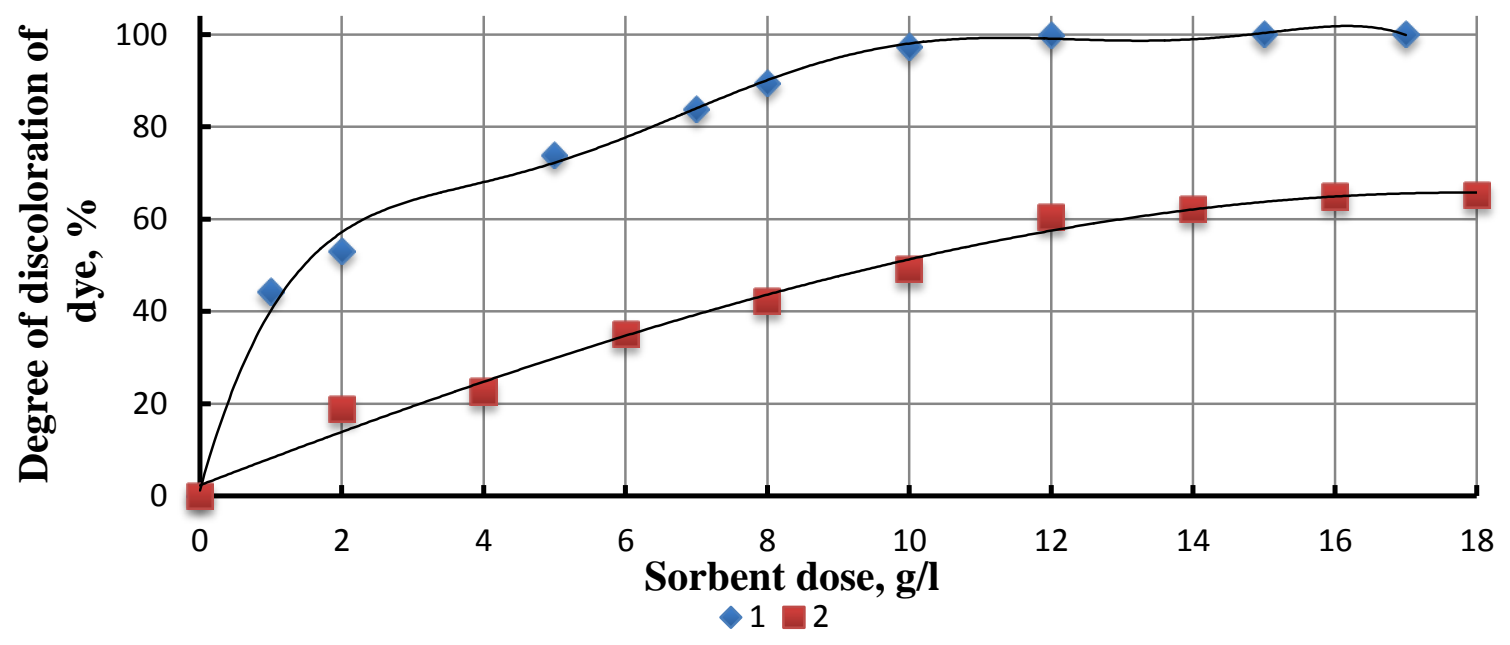

1 - synthesized sorbent; 2 - activated carbon F300

Figure 3. Effect of dose sorbents on removal efficiency of dye

Effect of initial dye concentration "Active brilliant blue KX" on the effectiveness of its removal from water

It was investigated the influence of dye concentration "Active brilliant blue $\mathrm{KX}$ " $(10 \ldots 70$ $\mathrm{mg} / \mathrm{l}$ ) on the degree of extraction of dye (Figure 4) under the following conditions: dose of sorbent $12 \mathrm{~g} / \mathrm{l}, \mathrm{pH}$ medium $4-4,3$, sorption duration $150 \mathrm{~min}$. On Figure 4 illustrates that the as greater the concentration of dye, as a more residual concentration of dye in water, and therefore a lower degree of its extraction. It could be related to association of the dye in adsorption layer by reducing the mobility of adsorbed and associated molecules and not may be compensated by the destruction of contaminant structures in the solution.

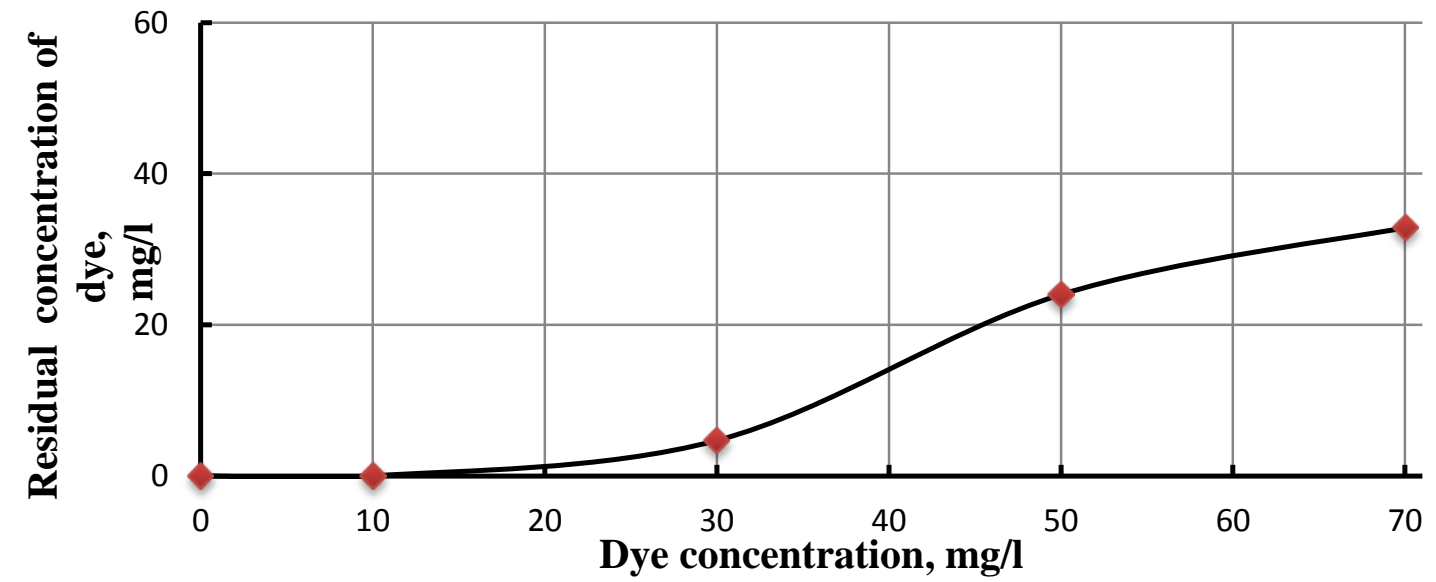

Figure 4. Effect of initial dye concentration "Active brilliant blue KX " on the residual content of dye by synthesized sorbent in water purification 


\section{Effect of adsorption duration and initial dye concentration "Active brilliant blue KX" to the extent of its extraction}

Investigation of the influence of the adsorption duration (from 20 to $180 \mathrm{~min}$ ) was conducted to determine the time at which the degree of removal of dye (concentration $10 \mathrm{mg} / \mathrm{l}$ ) reaches maximum (Figure 5). At that, doses of activated carbon F300 and synthesized sorbent composed $12 \mathrm{~g} / \mathrm{l}, \mathrm{pH}$ medium 4 - 4,3. It was found much better extraction efficiency contaminant (even on 100\%) by synthesized sorbent compared with activated carbon F300 at same duration of adsorption. It was established that the development due sorption process time of organic pollutants by synthesized sorbent has two high-speed periods, the first is represented by quick sorption and final with a relatively low rate of adsorption. In the first period sorption occurs on the outer surface of the sorbent, and the second, the process is limited by the speed of diffusion of pollutants to transport pores of sorbent [21]. With the increase of contact time, sorbent pores gradually filled and adsorption speed slows.

It was investigated the effect of adsorption of pollutants by synthesized reagent on its efficiency with dye concentration from $10 \mathrm{mg} / \mathrm{l}$ to $70 \mathrm{mg} / \mathrm{l}$, dose of reagent $12 \mathrm{~g} / \mathrm{l}, \mathrm{pH} 4-4,3$ respectively (Figure 6).

It was found that with the small and medium concentrations of organic pollutants $(10 ; 30$; $50 \mathrm{mg} / \mathrm{l}$ ) reagent dose in $12 \mathrm{~g} / \mathrm{l}$ is sufficient to achieve the degree of water purification to $93 \%$. At high concentrations of dye $(70 \mathrm{mg} / \mathrm{l})$ sorbent dose should be increased to $20 \mathrm{~g} / \mathrm{l}$, to achieve an acceptable rate of purification from pollutants to $87 \%$. At that with increasing doses of activated carbon F300 to $20 \mathrm{~g} / \mathrm{l}$ purification efficiency was only $65 \%$.

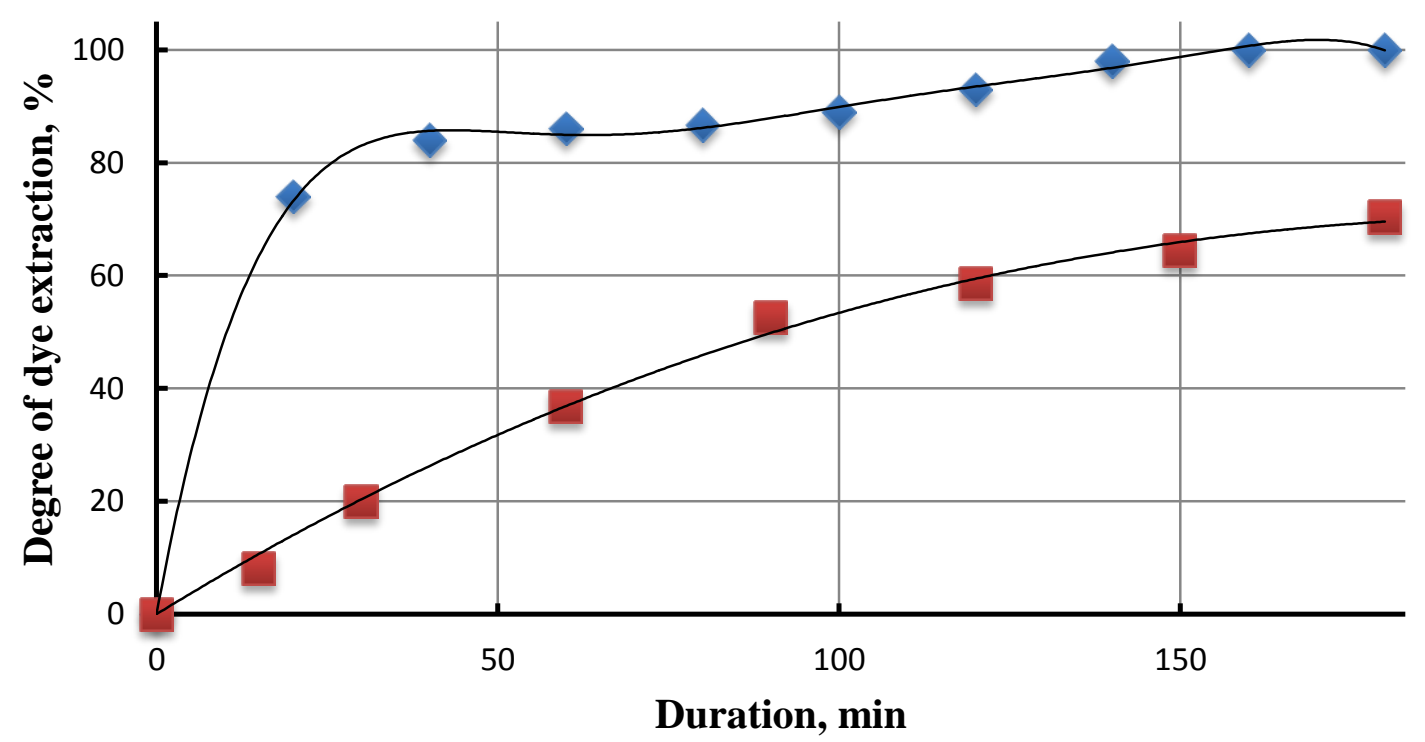

$\bullet 1 \square 2$

1 - synthesized sorbent; 2 - activated carbon F300

Figure 5. Effect of adsorption duration on the degree of extraction dye 


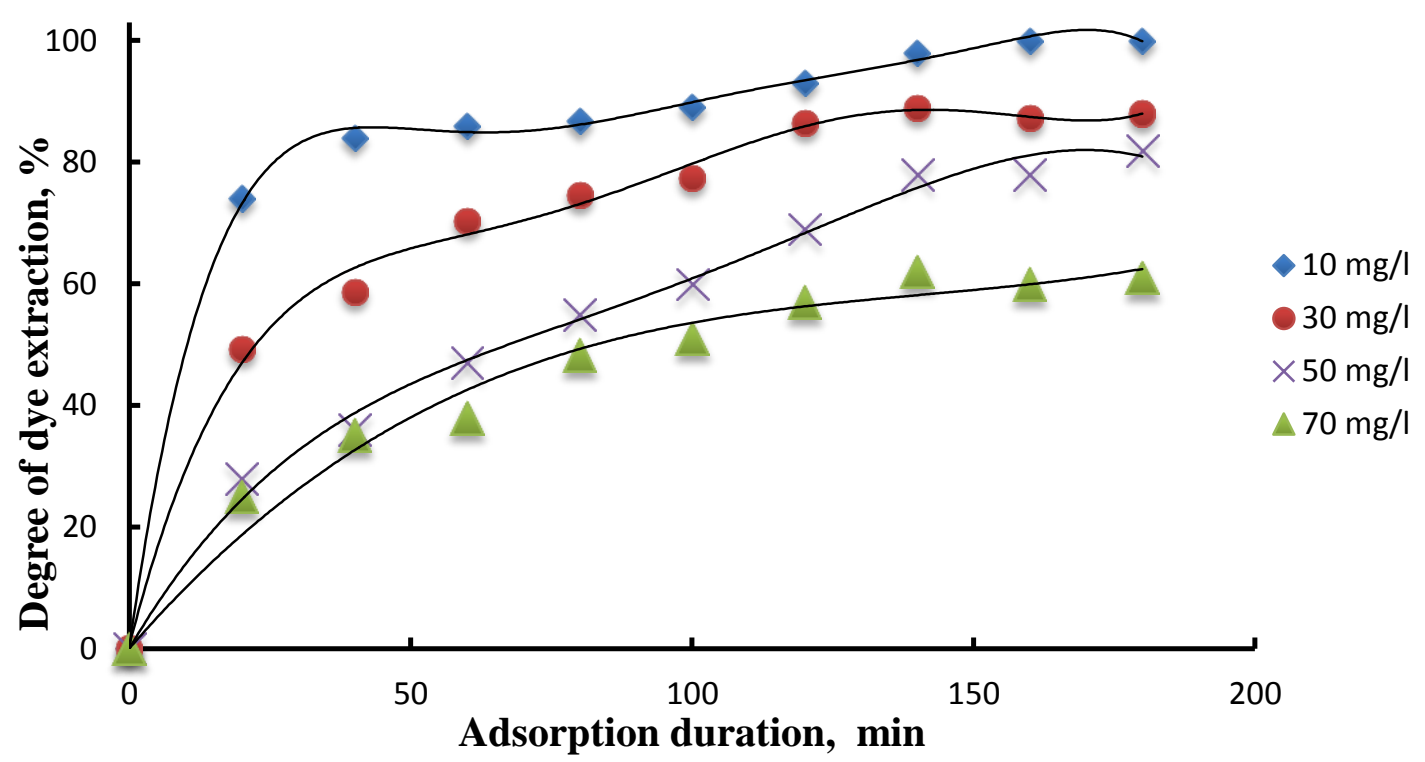

Figure 6. Effect of adsorption duration on the degree of extraction dye

\section{Conclusions}

The proposed sorption reagent derived from activated "red mud" and activated carbon brand F300 revealed sufficiently high sorption efficiency at wastewater treatment from the dye "Active brilliant blue KX". At the initial concentration of dye 10,30,50 mg/l achieved dye extraction to $84-100 \%$ in following conditions: $\mathrm{pH}$ medium $4-4,3$, the dose of sorbent $12 \mathrm{~g} / \mathrm{l}$, adsorption duration $150 \mathrm{~min}$. At high dye concentration, $(70 \mathrm{~g} / \mathrm{l})$ dose of synthesized sorbent should be increased to $20 \mathrm{~g} / \mathrm{l}$, to achieve an acceptable degree of purification to $87 \%$ at listed conditions of realization of the adsorption process.

Conducted research revealed that synthesized sorbent based on activated "red mud" and activated carbon (where the function of carrier do activated carbon) has potential for use in water treatment to remove organic dyes.

\section{УТИЛІЗАЦІЯ “ЧЕРВОНОГО ШЛАМУ” У СКЛАДІ НОВОГО ЕФЕКТИВНОГО СОРБЕНТУ У ВОДООЧИЩЕННІ}

\section{С.О. Кирій, І.В. Косогіна, І.М. Астрелін, В.Ю. Мосіюк}

Національний технічний університет України "Київський політехнічний інститут імені Ігоря Сікорського", Київ

e-mail: kosogina@email.ua

Перевірено ефективність реагентів, щзо були синтезовані з використанням "червоного иламу" від сполук органічного походження. Встановлено достатньо високу сорбиійну ефективність барвника "Активний яскраво-блакитний КX". При вихідних 
концентрачіях барвника 10, 30, 50 мг/дм досягається вилучення барвника на 84...100\% за наступних умов: рН середовища 4...4,3, доза сорбента 12 г/дм³, тривалість сорбиії 150 хв.

Ключові слова: червоний илам, сорбиійний реагент, сорбиія, утилізація, відходи, водоочистка

\title{
УТИЛИЗАЦИЯ «КРАСНОГО ШЛАМА» В СОСТАВЕ НОВОГО ЭФФЕКТИВНОГО СОРБЕНТА В ВОДООЧИСТКЕ
}

\author{
С.О. Кирий, И.В. Косогина, И.М. Астрелин, В.Ю. Мосиюк \\ Национальный технический университет Украины "Киевский политехнический институт \\ имени Игоря Сикорского", Киев \\ e-mail: kosogina@email.ua
}

Проверено эффективность реагентов, которые были синтезированы $c$ использованием "красного илама" от соединений органического происхождения. Выявлено достаточно высокую сорбционную эффективность красителя "Активный ярко-голубой КX". При исходных кониентрациях красителя 10, 30, 50 мг/дм ${ }^{3}$ достигается извлечение красителя на 84...100\% при следующих условиях: $р$ Н среды 4...4,3, доза сорбента 12 г/дм, продолжительность сорбции 150 мин.

Ключевые слова: красный илам, сорбционный реагент, сорбция, утилизация, отходы, водоочистка

\section{References}

1. 1. Renfortha P, Mayesb W. M., Jarvisc A. P., Burked I. T. (2012). Contaminant mobility and carbon sequestration downstream of the Ajka (Hungary) red mud spill: the effects of gypsum dosing. Science of the Total Environment,vol. 421-422, P. 253-259.

2. Bernesevich P. V, Kuzmenko P. K., Negentseva N. G. (1993). Ohrana okruzhayushchey sredy pri ekspluatatsii khvostokhranilishch. M.:Nedra, -123.

3. Galperin A. M., Freser B., Shef H.Yu. (2001) Tekhnogennyye massivy i okhrana okruzhayushchey sredy [2 izd.]. - M.: MGGU, - 534.

4. Mazur V. A., Gorschar V. I., Konopliov O. V. (2010). Ekolohichni problemy zemlerobstva. Tsentr naukovoyi literatury, 456.

5. Wang Y. Preparation of a Low-cost Adsorption Material from Red Mud and Bagasse [Text] / Y. Wang, L. Zhang, Y. Mo. // Materials and Manufacturing Processes. — 2016. — \#31. P. $162-167$.

6. Gupta V. K. Removal of Rhodamine B, Fast Green, and Methylene Blue from Wastewater Using Red Mud, an Aluminum Industry Waste [Text] / V. K.Gupta, Suhas, I. Ali, V. K. Saini. // Ind. Eng. Chem. Res.. — 2004. — \#43. — P. 1740-1747.

7. Khan T. Equilibrium uptake, isotherm and kinetic studies of $\mathrm{Cd}(\mathrm{II})$ adsorption onto iron oxide activated red mud from aqueous solution [Text] / T. Khan, S. Chaudhry, I. Ali. // Journal of Molecular Liquids. — 2015. — \#202. — P. 165-175.

8. Ni F. Preparation and characterization of a cost-effective red mud/polyaluminum chloride composite coagulant for enhanced phosphate removal from aqueous solutions [Text] / F. 
Ni, J. He, Y. Wang, Z. Luan. // Journal of Water Process Engineering. — 2006. — \#6. — P. 158— 165.

9. Sun Y. F. Technology for recovering iron from red mud by bayer process (In Chinese) [Text] / Y. F. Sun, F. Z. Dong, J. T. Liu. // Met. Mine. - 2009. - \#9. - P. 176-178.

10. Zhong L. Sub molten salt method recycling red mud [Text] / L. Zhong, Y. F. Zhang. // Chin. J. Nonferrous Met.. - 2008. — \#18. - P. 70-73.

11. Smirnov D. I. The investigation of sulfuric acid sorption recovery of scandium and uranium from red mud of alumina production [Text] / D. I. Smirnov, V. Molchanova. // Hydrometallurgy. - 1997. — \#45. - P. 249-259.

12. Xue A. The technological study and leaching kinetics of scandium from red mud (In Chinese) [Text] / A. Xue, X. H. Chen, X. N. Tang. // Nonferrous Metals Extr. Metall. — 2010. \#2. - P. 51-53.

13. Kalkan E. Utilization of red mud as a stabilization material for the preparation of clay liners [Text] / Kalkan. // 2006. — \#87. — P. 220-229.

14. Vangelatos I. Utilization of ferroalumina as raw material in the production of Ordinary Portland Cement [Text] / I. Vangelatos, G. N. Angelopoulos, D. Boufounos. // Journal of Hazardous Materials. - 2009. — \#168. - P. 473-478.

15. Zhang P. X. Red mud making tile black granular materials [Text] / Zhang. // Multipurp. Util. Miner. Resour. — 2000. — \#3. - P. 41- 43.

16. Xing G. The development of non-autoclaved brick made of red mud and fly ash [Text] / G. Xing, Z. Z. Jiao. // Rare Metals Cemented Carbides. - 1993. — \#6. - P. 154-163.

17. Albiniak A. Exfoliation and textural modification of anthracites [Text] / [A. Albiniak, G. Furdin, D. Begin та ін.]. // Carbon. - 1996. — No34. - C. 1329-1334.

18. Daulan C. Influence of anthracite pretreatment in the preparation of activated carbons [Text] / C.Daulan, S. B. Lyubchik, J. Rouzaud, F. Béguin. // Fuel. — 1998. — No77. - C. 495502.

19. Lyubchik S. B. Influence of chemical modification of anthracite on the porosity of the resulting activated carbons [Text] / S. B. Lyubchik, R. Benoit, F. Béguin. // Carbon. — 2002. No40. - C. 1287-1294.

20. Illan-Gomez M. J. Activated Carbons from Spanish Coals. 2. Chemical Activation [Text] / M. J.Illan-Gomez, A. Garcia-Garcia, C. Salinas-Martınez de Lecea, A. Linares- Solano. // Energy and Fuels. - 1996. - No10. — C. 1108-1114.

21. Alcañiz-Monge J. Insight into hydroxides-activated coals: Chemical or physical activation? [Text] / J. Alcañiz-Monge, M. J. Illán-Gómez. // Journal of Colloid and Interface Science. - 2008. - No318. - C. 35-41.

22. Utkov V.A., Meshin V. V. (1999). Promyshlennye sposoby pererabotky krasnykh shlamov. Sostoyanye problemy y napravlenyya yspol'zovanyya v narodnom khozyaystve krasnoho shlama, 9-17.

23. Губіна В.Г. Червоні шлами Миколаївського глиноземного заводу - цінна техногенна сировина [Текст] / В.Г. Губіна, В.М. Кадошніков. Геолого-мінералогічний вісник. - 2005. 一 № 2 .

24. Kyrii S. The Efficiency of Coagulation Treatment Wastewater by Reagent Obtained from Waste Alumina Production [Text] / Kyrii S., Kosogina I., Astrelin I. // Research bulletin of National Technical University of Ukraine "Kyiv Polytechnic Institute". — 2015. — \#6 (104). — P. $95-101$.

25. Kaganovskii A.M., Klimenko N.A., Levchenko T.M., Roda I.G. (1990). Adsorbtsyya orhanycheskykh veshchestv iz vody. Chimiya, 256. 